\title{
The Degree of Applying the Role- playing Strategy in Teaching English Language (EL)
}

\author{
Fatin Ssawalqa \\ Ministry of Education, Tafila Directorate of Education, Tafila, Jordan \\ Dr. Aallah Roud \\ Department $t$ of curricula and instruction \\ Faculty of Educational Sciences, Tafila Technical University \\ 66110. P.O. Box 179, Tafila, Jordan \\ Tel: 962-77-746-8618Ｅ-mail: atallah_roud@yahoo.com
}

Received: Jan. 23, 2017 Accepted: May 14, 2017 Published: May 14, 2017

doi:10.5296/jse.v7i2.11190 URL: https://doi.org/10.5296/jse.v7i2.11190

\begin{abstract}
For the importance of EL in individual's life, all those who interest in this field seek for strategies and methods that could facilitate learning EL.

This study aimed to identify the degree of applying the role- playing strategy in teaching English language for the basic stage from teachers' perspectives in Tafila Governorate schools. To achieve the purpose of the study, the researchers used descriptive analytic approach, and developed a questionnaire included (35) items. Reliability and validity were checked and showed appropriate results for the purpose of the study, and those who answered the questionnaire were (150) male and female teachers of basic stage in Tafila governorate, they formed the sample of the study with a ratio of (64\%) from the population of the study chosen by stratified randomly methods. The results indicated that the degree of applying role - playing strategy was mid for the instrument as a whole which included the domains of teaching English language (reading, listening, speaking, and writing). The writing domain came in the first rank; whereas, the reading domain came in the last rank. The results of Three-Way-ANOVA also showed that there are statistically significant differences at $(\alpha=$ 0.05) for the degree of applying role- playing strategy in teaching English language that attributed to gender, scientific qualification, and the interaction between gender, and scientific qualification, and the interaction between gender, experience, and scientific qualification.
\end{abstract}




\section{Macrothink}

There were also no statistically significant differences at $(\alpha=0.05)$ attributed to the years of experience. Finally, the results showed a positive effect in applying the role-play strategy in teaching EL. The study recommended that it is necessary for principals and supervisors to encourage teachers to use role - playing strategy in developing English language skills among the students of basic stage.

Keywords: Strategy, Role playing, English Language Skills, Basic stage, Teachers 


\section{Introduction and related literature:}

Learning a language is considered as a base in the process of teaching and learning; in addition to that, it is the key of cognitive development. Since English language is considered as an international language, It becomes necessary for every person to learn it. For mentioned reasons and others, most countries in the world adopted EL to be taught from the early stages in schools in addition to other institutions. EL is an essential subject in university learning because most of sciences in the world are taught by this language (khataybeh. 2000). Role-playing through drama is an effective strategy that leads to enjoyment for students and motivates them to be more self-confidence and to fix experience in their minds (Hamoh, 2000).

Role-playing was defined as one of the learning methods and activities which symbolizes an artificial attitude, which creates social relationships between individuals and leads to solutions for the problem that learners face (Joudah, 2013). Planning for teaching by role-playing strategy is the responsibility of the teacher and it should go through the following steps (Hosari, 2015):

- Forming the main idea.

- Forming the problem.

- Forming the goals.

- Limiting the attitudes and roles.

- Dramatizing the instructional attitude.

- Analyzing the instructional attitude.

- Generalizations.

Alabsi (2016) conducted a study aimed to recognize the effectiveness of the role-play strategy in teaching vocabularies in EL. The sample consisted of (40) female students divided into control group and experimental group. She prepared a test based on English curriculum consists of (42) items. The results indicated that there are statistically significant differences between the two groups and the two methods of teaching (traditional method and teaching by role-play strategy) in favor of the experimental group.

Zgoul (2015) conducted a study aimed to recognize the reality of using role-play and story-telling strategies in developing human rights concepts towards the basic stage students. Two questionnaires were prepared to measure the study variables on the sample of the study which consisted of (181) male and female teachers in UNRWA schools in Gaza stripe (2013/2014). The results indicated that there is no significant difference attributed to the variables of gender, specialization, educational region, and experience.

The findings showed that there is significant difference attributed to the qualification variable in favor of higher qualification holders, there is a significant difference in teachers estimations in using role-play and story-telling strategies according to the educational stage 
variable in favor of elementary stage; whereas, there are no significant differences relating to the obstacles and reality of using role-play and story-telling and in developing the concepts of human rights.

Barimani (2013) conducted a study aimed at learning and memorizing vocabularies in EL through role-play strategy in one of EL institution in Iran. The sample consisted of (75) students divided into two groups: experimental group (37) students, and control group (38) students. The experimental group was taught by using role-play strategy and the control group was taught by traditional method.

The results indicated that there is a big difference between the two ways of teaching in favor of the experimental group.

Allabadi (2013) conducted a study aimed at identifying the effect of employing drama in developing life skills in Arabic language (AL) for the fourth basic grade in north of Gaza. The sample consisted of (84) female students chosen randomly. The results showed that there are statistically significant differences at $(\alpha \leq 0.05)$ that pointed out to the effect of employing drama in developing life skills in Arabic Language.

Awbrey, et al, (2008) conducted a study aimed at increasing the effectiveness of social concepts towards elementary schools students by using literature and role-play. The sample consisted of (89) students. The results indicated that most of the students are in need for developing their social concepts regarding integrity, respect, cooperation, and responsibility through using role-play strategy.

\section{Problem and questions of the study}

Through the researchers experience, they noticed that students are so weak in English language. This could be ensured by the low results of students in General secondary examination in English language.

The study aims to answer the following questions:

1-What is the degree of applying role-playing strategy in teaching EL for the basic stage from the teachers' perspectives in Tafila Governorate?

2-Are there statistically significant differences attributed to the variables of gender, experience, and scientific qualification, and the interaction between them in the estimations of the sample individuals regarding to the degree of applying role-playing in teaching EL?

\section{Significance of the study}

The study may provide the decision makers in the Ministry of Education, definitely the curricula designers with the importance of using role-playing strategy by the teachers of EL. In addition to that, it may provide those who interest in this area with qualitative information about applying the role-playing strategy in teaching EL. in Tafila Governorate.

\section{Limitations of the study}

The study is limited to the basic schools in Tafila Governorate for the academic year 
2015/2016.

\section{Methodology}

The researchers used the analytic descriptive method based on studying the phenomenon as it is and analyzing and expressing it statistically.

\subsection{Population of the study}

The population of the study consists of (235) male and female teachers who teach EL in basic schools. The male teachers were (82) with a ratio of $(35 \%)$; whereas the female teachers were (153) with a ratio of $(65 \%)$

\subsection{Sample of the study}

The sample consists of (52) male teachers and (98) female teachers with a total of (150) male and female teachers with a ratio of $(\% 64)$ of the population.

\subsection{Instrument of the study}

After reviewing the theoretical literature and previous studies relating to the study, the researchers developed an instrument including two parts. The first part was about personal information indicating the gender, experience, and scientific qualification answered by the sample individuals. The second part consists of four domains distributed as follows:

Reading domain with (8) items, listening domain with (7) items, speaking domain with (10) items, and writing domain with (10) items. Likert scale was used for defining the means as follows: (Very big degree, big degree, mid degree, little degree, and very little degree). According to that, means were computed as: low (1-2.33), mid (2.34-3.67), and high (3.68-5).

\subsection{Validity of the instrument}

The researchers distributed the instrument to a jury of referees who are experts and specialists in educational sciences and psychologists to make sure that the instrument is valid. The ratio of agreement of those referees was (\%87) which is fit for the purpose of the study according to (Alnabhani 2008) who mentioned that the experts adopted the ratio of $(\% 80)$ to be appropriate for such studies.

\subsection{Reliability of the study}

The reliability was computed through test-re test applied on (25) male and female teachers from the population of the study. Also, the internal consistency (Chronach alpha) was computed as table1shows: 
Table 1. Reliability coefficients of the instrument

\begin{tabular}{lll}
\hline Domain & Test Retest & chronbuch \\
\hline Reading & $7280 .^{* *}$ & 0.82 \\
Listening & $8050 .^{* *}$ & 0.80 \\
Speaking & $8930 .^{* *}$ & 0.77 \\
Writing & $7850 . * *$ & 0.78 \\
\hline
\end{tabular}

) $0.01 \leq \alpha^{* *}($

The figures in table (1) indicated that the reliability coefficient is acceptable for the purpose of this study.

\section{The results}

For answering question no. one which states: What is the degree of applying role-play strategy in teaching EL for the basic stage in Tafila Governorate from the teachers perspectives?. Means and standard deviations for domains and for the whole instrument were computed as table (2) shows:

Table 2. Means and standard deviations for the study domains

\begin{tabular}{llllll}
\hline No. & Item & MEAN & SD & Order & Rank \\
\hline $1-8$ & Reading & 2.98 & 0.83 & 4 & mid \\
$9-15$ & Listening & 3.17 & 0.81 & 3 & mid \\
$16-25$ & Speaking & 3.24 & 0.66 & 2 & mid \\
$26-35$ & Writing & 3.32 & 0.62 & 1 & mid \\
& Total & 3.18 & 0.50 & & mid \\
\hline
\end{tabular}

It is noticed from the figures in table 2 that the total mean for the instrument as a whole to the degree ofapplying role-play strategy in teaching EL was mid with a mean of (3.18) and standard deviation of (0.50) the writing domain came first in ranking with a mean of (3.32) and standard deviation of (0.62), followed by speaking domain with a mean of (3.24) and standard deviation of (0-66). Listening domain came in the third rank with a mean of (3.17) and standard deviation of (0.81), whereas, the reading domain came in the last rank with a 
mean of (2.98) and standard deviation of (0.83).

As a completion for answering question no. one, each domain was analyzed according to its items. Table 3 represents the means and standard deviations for reading domain.

Table 3. Means and standard deviations for reading domain

\begin{tabular}{llllll}
\hline No. & Item & MEAN & SD & Order & Rank \\
\hline $1 \quad$ Each student reads the paragraphs of his role in EL. & 3.04 & 1.08 & 5 & mid
\end{tabular}

2 More than one student participatein reading the lesson 2.95

$1.07 \quad 6 \quad \mathrm{mid}$ aloud.

3 A student acts as a bulletin announcer in EL. Inside the $\begin{array}{llll}3.05 & 1.20 & 3 & \text { mid }\end{array}$ classroom.

$4 \quad$ A Student presents a speech in EL in school broadcast $3.08 \quad 1.14 \quad 2 \quad 2 \quad$ mid in front of the students of school.

5 Students read text of drama in EL.

$\begin{array}{llll}3.05 & 1.19 & 3 & \mathrm{mid}\end{array}$

6 A part of the class is given for a student to read a text 2.29

$1.29 \quad 8$ low of play in EL.

$7 \quad$ Students read songs in EL. aloud

$\begin{array}{llll}3.25 & 1.22 & 1 & \mathrm{mid}\end{array}$

8 A student says a word and another one gives the $\begin{array}{lllll}2.75 & 1.16 & 7 & \mathrm{mid}\end{array}$ antonym of it

Total

$2.98 \quad .83 \quad 0$

mid

The figures in table 3 showed that all the means of the items were mid except item no. 6 came low with a mean of 2.29 and standard deviation of 1.29. The highest estimation was for item 7 
with a mean of 3.25 and standard deviation of 1.22 .

Table 4 represents the means and standard deviations for listening domains as follows:

Table 4. Means and standard deviations for listening domain

\begin{tabular}{|c|c|c|c|c|c|}
\hline No. & Item & MEAN & $\mathrm{SD}$ & Order & Rank \\
\hline 9 & Students listen to recorded texts & 3.20 & 1.32 & 2 & mid \\
\hline 10 & $\begin{array}{l}\text { Students answer questions about a text } \\
\text { they listened to. }\end{array}$ & 3.03 & 1.13 & 7 & mid \\
\hline 11 & $\begin{array}{l}\text { Students listen to the dialogues inside } \\
\text { the classroom. }\end{array}$ & 3.17 & 1.02 & 3 & $\operatorname{mid}$ \\
\hline 12 & $\begin{array}{l}\text { Students repeat the pronunciation of } \\
\text { the words he listened to. }\end{array}$ & 3.04 & 1.26 & 6 & $\operatorname{mid}$ \\
\hline 13 & $\begin{array}{l}\text { Students listen to the teacher's } \\
\text { pronunciation of some words. }\end{array}$ & 3.51 & 1.14 & 1 & $\operatorname{mid}$ \\
\hline 14 & $\begin{array}{l}\text { Students chatthe songs in EL. After } \\
\text { listening to them }\end{array}$ & 3.09 & 1.16 & 5 & mid \\
\hline 15 & $\begin{array}{l}\text { Student explains the meanings of } \\
\text { vocabulary of a listening text }\end{array}$ & 3.15 & 1.15 & 4 & mid \\
\hline & Total & 3.17 & .810 & - & mid \\
\hline
\end{tabular}

In table (7), it is indicated that all the means of the items were mid.The highest estimation was for item no. (13) with a mean of (3.51) and standard deviation of (1.14) and the lowest estimation was for item (10) with a mean of (3.03) and standard deviation of (1.13).

Table 5 represents the means and standard deviations for speaking domain as follows: 
Table 5. Means and standard deviations for speaking domain

\begin{tabular}{llllll}
\hline No. & Item & MEAN & SD & Order & Rank \\
\hline 16 & $\begin{array}{l}\text { a teacher prepares a situational dialogue } \\
\text { in EL. Between two students }\end{array}$ & 3.03 & 1.25 & 10 & mid
\end{tabular}

17 a teacher participates a student with $3.11 \quad 1.23$

$7 \quad \mathrm{mid}$ drama dialogue in EL.

$\begin{array}{llllll}18 & \text { a teacher trains students on teacher style } & 3.94 & 1.15 & 1 & \text { high }\end{array}$ in EL.

19 a teacher says a verb and students act the $3.30 \quad 1.00$

$3 \quad \operatorname{mid}$ motion

20 Students act a scene in real life situation. $3.14 \quad 1.06 \quad 6 \quad 6 \quad$ mid

21 students take the role of teacher in $3.20 \quad 1.08 \quad 5 \quad$ mid explaining a lesson in EL.

22 students act a radio program between a $3.06 \quad 1.06$ responsible and a citizen in EL.

23 Students act a role between a salesman $3.06 \quad 1.13$ and a buyer in EL.

24 a teacher presents a subject for $3.21 \quad 1.10 \quad 4 \quad 4 \quad$ mid discussion and students give their opinions.

25 a teacher presents an idea for a dialogue 3.3 between an opposes group and supporter group. 
In table (5), the figures showed that the items came between high estimation for item (18) with a mean of (3.94) and standard deviation of (1.15), and mid estimation for the other items. The lowest estimation was for item (16) with a mean of (3.03) and standard deviation of (1.25).

Table 6 represents the means and standard deviations for writing domain.

Table 6. Means and standard deviations for writing domain

No. Item MEAN SD Order Rank

26 Student writes paragraphs in sequence on the white board $\begin{array}{llll}3.46 & 0.96 & 2 & \text { mid }\end{array}$ in EL.

27 Students correct others errors in spelling.

$\begin{array}{llll}3.53 & 1.01 & 1 & \mathrm{mid}\end{array}$

28 Student writes what he listens to from a CD or recorder.

$\begin{array}{llll}2.98 & .840 & 10 \quad \text { mid }\end{array}$

29 Student writes composition in EL about real roles in life.

$\begin{array}{llll}3.34 & 1.19 & 5 & \mathrm{mid}\end{array}$

30 Student constructs meaningful sentences from scattered $\begin{array}{lllll}3.34 & 1.10 & 5 & \text { mid }\end{array}$ words.

31 a teacher asks students to put punctuation marks for a $3.24 \quad 1.15 \quad 9 \quad$ mid text of a dialogue.

32 students describe an event through writing

$\begin{array}{llll}3.30 & 1.12 & 7 & \mathrm{mid}\end{array}$

33 a teacher asks students to write about a subject defined 3.26

$1.14 \quad 8 \quad$ mid from the teacher.

34 Student expresses himself through writing.

$3.39 \quad 1.15 \quad 4 \quad$ mid

35 teacher asks a student to write a letter on behalf of an $\begin{array}{llll}3.44 & 1.18 & 3 & \text { mid }\end{array}$ expatriate to his native land in EL

Total $3.32 \quad .620-\quad$ mid

In table (6), all the estimations for all items were mid. The highest mean was for item (27) with a mean of (3.53) and standard deviation of (1.01), and the lowest estimation was for item (28) with a mean of (2.98) and standard deviation of (0.84). 
For answering question no. two which runs: (Are there any statistically significance differences at $(\alpha=0.05)$ in the estimation of sample individuals attributed to the variables of gender, experience, and scientific qualifications, and the interaction between them in applying role-play strategy in teaching EL?). Means and standard deviations were computed as table (7) shows:

Table 7. Means and standard deviations for the degree of applying the role- playing strategy in teaching English language according to gender, experience and qualifications of teachers.

\begin{tabular}{|c|c|c|c|c|}
\hline gender & Experience & Qualification & Mean & SD \\
\hline \multirow[t]{6}{*}{ Male } & $1-5$ & bachelor & 2.78 & 0.118 \\
\hline & & higher than bachelor & 3.08 & 0.067 \\
\hline & $6-10$ & bachelor & 2.76 & 0.117 \\
\hline & & higher than bachelor & 3.24 & 0.183 \\
\hline & 11 and more & bachelor & 3.04 & 0.156 \\
\hline & & higher than bachelor & 3.09 & 0.125 \\
\hline \multirow[t]{6}{*}{ Female } & $1-5$ & bachelor & 2.96 & 0.383 \\
\hline & & higher than bachelor & 3.56 & 0.397 \\
\hline & $6-10$ & bachelor & 3.31 & 0.509 \\
\hline & & higher than bachelor & 3.66 & 0.571 \\
\hline & 11 and more & bachelor & 3.03 & 0.539 \\
\hline & & higher than bachelor & 4.07 & 0.224 \\
\hline
\end{tabular}

It is noticed that, there are visible differences in the means. In order to be sure if there are statistically significant differences or not, 3 Way ANOVA was used as table (8) shows: 
Table 8. 3 Way ANOVA for the effect of to gender, experience and qualifications of teachers upon the degree of applying the role- playing strategy in teaching English language

\begin{tabular}{|c|c|c|c|c|c|}
\hline Source & Sum of squares & df & Mean squares & $\mathrm{F}$ & Sig. \\
\hline gender & 5.110 & 1 & 5.110 & 31.730 & $* 0.000$ \\
\hline Experience & 0.752 & 2 & 0.376 & 2.335 & 0.101 \\
\hline Qualification & 5.996 & 1 & 5.996 & 37.232 & $* 0.000$ \\
\hline gender * Experience & 0.135 & 2 & 0.068 & 0.420 & 0.658 \\
\hline gender* Qualification & 1.034 & 1 & 1.034 & 6.421 & $* 0.012$ \\
\hline Experience $*$ Qualification & 0.090 & 2 & 0.045 & 0.280 & 0.756 \\
\hline gender* Experience Qualification * & 1.602 & 2 & 0.801 & 4.973 & $* 0.008$ \\
\hline Error & 22.223 & 138 & 0.161 & & \\
\hline Total & 1553.742 & 150 & & & \\
\hline
\end{tabular}

The results in table (8) indicated that there are statistically significant differences in applying role-play strategy in teaching EL attributed to the variables of gender, scientific qualifications, the interaction between gender and qualification, and between gender, qualification and experience, for the high value of $(\mathrm{F})$ regarding to gender, the differences were in favor of females with a mean of (3.43) and the mean for males was (2.99) as table (7) shows.

According to scientific qualification, it was in favor of higher than bachelor and more, and about the interaction between gender and qualification it was in favor of females who havehigher than bachelor and more. The interaction between gender, qualification, and experience came in favor of females of (11) year experience and more and who have higher than bachelor and more.

The results showed that there are no statistically significant differences attributed to the variable of experience, the interaction between gender and experience, and the interaction between experience and qualification.

\section{Discussion}

The results of the first question indicated that the mean of the degree of applying the role play for the instrument as a whole was mid. The writing domain came in the first rank; this 
may be due to the importance of writing which expresses the extent of students use from the instructional material

In addition to that, the writing process clarifies the points of strength and weakness for the instructional material. It also helps in achieving the goals of teaching process, and leads students to mastering other language skills.It is found that item (27) which states(Students correct others errors in spelling)got the highest Estimation, and this may be due to creating competition between students, and increasing their interest in learning.

The item (28) which runs (Student writes what he listens to from a CD or recorder) got the lowest estimation, and this could be attributed to the fact that there are big numbers of students.

In the class which does not give sufficient time for students to listen more than once for a CD or recorded material - speaking domain came in the second rank the item (18) which states (a teacher trains students on teacher style in EL) got the highest estimation. this could be due to the importance of drama in installing the linguistic concepts students, in addition to using school activities in simple and aiming plays by students.

In the class which does not give sufficient time for students to listen more than once for a CD or recorded material.

The lowest item was (16) which runs (a teacher prepares a situational dialogue in EL. Between two students).

This could be explained that the reason may refer to less interest of teachers in preparing a conversational situations implemented by students.

The listening domain came in the third rank.

The item (13) which states (Students listen to the teacher's pronunciation of some words) got the highest estimation and this may be attributed to the fact that a teacher reads the lesson, pronounces the words, and uses various means as recorders which facilitate understanding and correct pronunciation and ultimately good listening. Item (10) which runs (Students answer questions about a text they listened to) got the lowest estimation this may due to lack of concentration from students because of curnulative weakness from the beginning of learning.

The reading domain came in the last rank, where item no (7) which runs (Students read songs in EL. Aloud ) got the highest mean and this due to the importance of songs in strengthening the language of students since the songs are exciting and increase the ability of students attention and motivation.

Item no.(6) which states (A part of the class is given for a student to read a text of play in EL) got the lowest estimation and this could be attributed to short duration of classes, and lack of seriously of teachers in presenting non curriculum materials.

The results of this study disagreed with the results of the study of( Zgoul) definitely for the variables of gender and experience, whereas, they meet with the results of(Alabsi, Allabadi, 
andAwbrey) since the results of their studies were in favor of experimental groups who were taught by role play.

The results of question two indicated that there are significant differences in the degree of applying role - play strategy in teaching EL. Attributed to the variable of gender and qualification in favor of females, this due to the interest of females in teaching they also have the ability to apply and attend any training program or course which serve the process of teaching. Pertaining qualification, the results came in favor of high diploma and more since they have much information and skills. This result meets with (Zqoul, 2015)

According to the interaction between the variables, the results came in favor of females holding higher than bachelor. This could be explained that in rough studying for higher qualifications, the subjects urge teachers to use appropriate instructional strategies. Regarding the interaction between gender, qualification and experience, the results came in favor of females with 11 - year experience and more and the holders of high diploma and more because of the cumulative experience during long service.

The results indicated that there are no significant differences attributed to the variable of experience for the low value of (f) and the reason is that all the teachers have the same training courses, teach the same textbooks, and have the same instructional environment.

The positive effects indicated in the results of applying role-play strategy in teaching EL may refer to the activities and practice that a student uses in comparison with the traditional method where the student is only a receiver.

\section{Conclusion:}

The conclusions of this study point out that the teachers use role-play strategy came in a mid mean, and it also indicated that this strategy is employed in writing skill more than other domains in teaching the skills of English language.

\section{Recommendations}

The researchers recommend the following: increasing the number of training courses focusing on using role- play strategy in teaching EL, encouraging students to use EL in real life situations and school activities, following up teachers in applying role- play strategy by supervisors, encouraging teachers to apply drama inside the classroom to enhance EL skills.

\section{References}

Alabsi, T. (2016). The Effectiveness of role play strategy in teaching vocabulary. Theory and practice in language studies, 6(2), 227-234. https://doi.org/10.17507/tpls.0602.02

Allabadi, M. (2013).the impact of Employing Drama in life Skills Development in Arabic language among fourth Basic Female Students in Northern Gaza Governorate. Unpublished Master thesis. Al-AZhar University. Gaza.

Alnabhani,Y. (2008). Current Methods in Teaching and Learning. Scientific Yazoori Dar.

Awbrey, C. et al. (2008). Increasing social skills of elementary students the use of Literature 
and role playing. Education Resources Information center.

Barimani, S. (2013). Contrastive study on learning and memorization vocabulary through role- play among female learner, journal of academic and applied Studies, 3(1), 1- 19.

Hamoh.B. (2000). The Impact of Drama for texts literacy on Reading Comprehension of the Seventh Basic class in Jordan. Unpublished Master thesis. Jordan University. Jordan.

Hosari,A. (2015). Common Instruction Methods. Amman. Dar Haneen for publication and distribution.

Joudah, M. (2013). The Effect of a suggested program based on a Strategy of Role-playing in Developing Engineering thinking among Fifth basic students in Gaza in Mathematics and their attitudes to towards it. Unpublished PHD thesis Faculty of Education. Al-HananUniversity.Tripoli. Lebanon

Khataybeh,M. (2000). Measuring Reading Skill Within Memorizing comprehension. and Application among the students of field of English Language teacher in Mutah University. Mutah Journal for researches and studies.

Zgoul, S. (2015). The reality of using Role- playing and Story- telling Strategies in developing Human Rights concepts Among the Basic Stage students. Unpublished Master thesis. Faculty of Education, AL-AZhar University, Palestine. 